\title{
Prevention of Bone Bridge Formation Using Transplantation of the Autogenous Mesenchymal Stem Cells to Physeal Defects: An Experimental Study in Rabbits
}

\author{
L. PLÁNKA ${ }^{1}$, A. NEČAS ${ }^{2}$, P. GÁL ${ }^{1}$, H. KECOVÁ ${ }^{2}$, E. FILOVÁ ${ }^{3}$, L. KŘEN ${ }^{4}$, P. KRUPA $^{5}$ \\ ${ }^{1}$ Department of Pediatric Surgery, Orthopaedics and Traumatology, the Faculty Hospital Brno, Czech Republic \\ ${ }^{2}$ Department of Surgery and Orthopaedics, Small Animal Clinic, Faculty of Veterinary Medicine, \\ University of Veterinary and Pharmaceutical Sciences Brno, Czech Republic \\ ${ }^{3}$ Institute of Experimental Medicine of the Academy of Sciences, Prague, Czech Republic \\ ${ }^{4}$ Department of Pathology, the Faculty Hospital Brno, Czech Republic \\ ${ }^{5}$ Department of Medical Imaging, St. Anne's University Hospital, Masaryk University, Brno, Czech Republic
}

Received December 12, 2006

Accepted December 28, 2006

\begin{abstract}
Plánka L., A. Nečas, P. Gál, H. Kecová, E. Filová, L. Křen, P. Krupa: Prevention of Bone Bridge Formation Using Transplantation of the Autogenous Mesenchymal Stem Cells to Physeal Defects: An Experimental Study in Rabbits. Acta Vet. Brno 2007, 76: 253-263.

Physeal cartilage is known to have poor self-repair capacity after injury. Evaluation of the ability of cultured mesenchymal stem cells to repair damaged physis is the topic of current research. In 10 immature New Zealand white rabbits autogenous mesenchymal stem cells were transplanted into a iatrogenic physeal defect in a lateral portion of the distal growth plate of the right femur. The same defect without stem cells transplantation in the left femoral distal physis served as a control. In our study, we used our own technique of implantation of MSCs with a newly modified gel scaffold (New Composite Hyaluronate/Collagen Type I/Fibrin Scaffold). The rabbits were euthanized 4 months after transplantation. Bone length discrepancy and valgus deformity were measured from femoral radiographs. Healing of the defect was investigated histologically. The ability of mesenchymal stem cells to survive and promote cartilage healing in the physeal defect was assessed by immunofluorescence.

Average difference in femur length measured from surgery to euthanasia (4 months) was $0.61 \pm 0.19 \mathrm{~cm}$ after preventive transplantation of MSCs in the right femur, but only $0.11 \pm 0.07$ $\mathrm{cm}$ in the left femur. Average angular (valgus) deformity of the right femur with MSCs preventively transplanted to iatrogenically damaged distal femoral physis was $1.2 \pm 0.72^{\circ}$. Valgus deformity in the left femur was $5.4 \pm 2.5^{\circ}$.

Prophylactic transplantation of autogenous mesenchymal stem cells to iatrogenically damaged distal growth plate of the rabbit femur prevented a bone bridge formation and resulted in healing of the physeal defect with hyaline cartilage. Immunofluorescence examination showed that the chondrocytes newly formed in growth zone are the result of implanted MSCs differentiation. Femur growth in traumatized physis was maintained even after transplantation of autogenous MSCs. As compared with the opposite femur (with physeal defect but without transplanted MSCs), the bone showed no significant shortening or valgus deformity $(p=0.018)$.
\end{abstract}

Growth plate injury, physis, growth arrest, limb deformity

Physeal fractures belong to serious bone injuries occurring relatively often both in children and immature animals. In children, physeal injuries represent $6-15 \%$ of all fractures (Rogers 1970). However, the incidence of injuries of individual types of physis varies. Fractures of the distal physis make approximately $20 \%$. Traumas of the proximal growth plate of humerus, distal physes of tibia, fibula, humerus and femur represent $2-10 \%$ of all bone injuries (Ashcraft 2005). In dogs, physis is affected in approximately one fourth to one third of fractures of long bones of limbs with predominating Salter-Harris II injury type (Dvořák et al. 2000; Maretta and Schrader 1983; Salter and Harris 2001). Most often, dogs suffer from injuries of the distal growth plate of femur. Injuries of

Address for correspondence:

MUDr. Ladislav Plánka, Ph.D.

Department of Pediatric Surgery, Orthopedics and Traumatology

Medical Faculty, Masaryk University

Černopolní 9 ,

66263 Brno, Czech Republic

Phone: +420532234360

Fax: +420 532234365

E-mail: lplanka@seznam.cz

http://www.vfu.cz/acta-vet/actavet.htm 
growth plates that follow in frequency order are fractures of the distal physis of humerus, proximal physis of femur, distal physis of ulna, proximal physis of tibia and distal physis of tibia (Maretta and Schrader 1983).

Except for humerus, limb long bone injuries are most often associated with damage of physis (e.g. distal physis of the ulna or distal physis of the femur) which is crucial for the longitudinal growth of a bone (Ols on et al. 1975; Maretta and Schrader 1983). Poor regeneration capacity of cells in damaged growth plates leads to the formation of a bridge at the site of a physeal injury. Experiments showed that if the bone bridge takes up $7-9 \%$ of the physis area, injury of the long bone physis results in growth defect of a given bone (Gál et al. 2002; Janarv et al. 1998). In dependence on localization (central, peripheral) of a bone bridge, the affected limb might become shorter or show angular deformity. Also, a combination of both these growth abnormalities might be observed (Campbell et al. 1959; Ford and Key 1956; Key and Ford 1958). It has been reported that $25-35 \%$ of physeal fractures in humans lead to shortening or deformity of the injured bone and that $10 \%$ of these fractures result in functional problems with the affected limb (Mann and Rajmaira 1990; Mizuta et al. 1987). Bone deformity is associated with $5-10 \%$ of physeal closures in dogs. In most of these cases, it is necessary to perform corrective osteotomy to restore normal limb functions (Maretta and Schrader 1983). Limb deformity affects mostly medium and large breeds of dogs that are injured before 5 months of age (the most severe deformities develop after SalterHarris injuries of the distal physis of ulna) (Fox 1984; Henney and Gambardella 1989; Piermattei and Flo 1990).

Surgical correction of both leg length discrepancy and deformity is a challenging procedure in both human and veterinary orthopaedics. Over the years, varying degrees of success have been achieved with clinically used methods of the corrections of limb shortening and angular deformity (Bright 1984; Broughton et al. 1989; Klassen and Peterson 1982; Langenskiold 1981; Macksoud and Bright 1989; Williamson and Staheli 1990). More recently, cultured chondrocyte (Foster et al. 1990; Lee et al. 1998; Len nox et al. 1983) and mesenchymal stem cell (Chen et al. 2003) transplantations represent an attractive and promising approach to treat physeal cartilage defects. Since recently, another promising option of the treatment of partial physeal growth arrest is bioengineering (Lee et al. 2003). Unfortunately, all attention has been focused on the treatment of already formed bone bridge and related deformities, and shortening of the affected bone. One of the ways how to avoid complicated and protracted surgical therapy of these consequences of physeal closure might be prevention of the bone bridge formation. A primary concern is continued growth from the traumatized physis. Such a preventive approach to long bone growth plate injuries of limbs could prevent the development of limb deformities that are difficult to treat. We reported previously on the successful use of the experimental transplantation of autogenous chondrocyte graft into the area of iatrogenically damaged physis in pigs. We concluded that the transplantation of the autogenous chondrocyte graft into the iatrogenically damaged physis in pigs can prevent the bone bridge formation and growth arrest (Gál et al. 2002; Nečas et al. 2006).

Recently, we investigated a technique of autogenous mesenchymal stem cell transplantation into a iatrogenically damaged growth plate. The purpose of the study was to evaluate the ability of cultured MSCs to elicit repair at the site of a distal femoral physeal defect in the rabbit.

The hypothesis under investigation was that transplantation of autogenous mesenchymal stem cells into an experimental physeal defect can promote growth plate healing by differentiation into chondrocytes, and thereby prevent a bone bridge formation, bone shortening and angular deformity in rabbits. 


\section{Materials and Methods}

The New Zealand white rabbit (from a facility approved for laboratory animal breeding) was chosen as the experimental animal model. Ten healthy individuals, 5 males and 5 females, of the same age (7 weeks) and approximately same weight $(2.38 \pm 0.38 \mathrm{~kg})$ were included in the study.

Preparation of the stem cells with scaffold

Twenty-one days before transplantation of autogenous MSCs, a bone marrow blood sample was taken under general anaesthesia from wings of both ilia in each rabbit to culture MSCs. Hypodermic needle (20G/40 mm) was used to take bone marrow blood in the syringe $(5 \mathrm{ml}$, Baxter) with $2 \mathrm{ml}$ of PBS (Phosphate Buffered Saline, Dulbecco), 2\% FBS (Fetal Bovine Serum, StemCell) and heparin at the dose of $5 \mathrm{IU} / \mathrm{ml}$.

Culture medium Dulbecco's Modified Eagles Medium (DMEM) (Gibco Laboratories, Life Technologies, Grand Island, NY) supplemented with $10 \%$ FBS and gentamycin $(50 \mathrm{mg} / 1$, GENTAMYCIN, Sigma) was used. Cells were cultured for 21 days on culture plates with the area of $0.75 \mathrm{~cm}^{2}$. The total number of isolated nuclear cells ranged from 15 to 30 million nuclear cells per each isolation. The cultured bone marrow mesenchymal stem cells were labelled by lipophilic fluorescent stain CM-DiI (Chloromethylbenzamido derivate of DiI, CellTracker ${ }^{\mathrm{TM}} \mathrm{CM}-\mathrm{DiI}$, Invitrogena) at the concentration of $5 \mu \mathrm{l} / 2.5 \mathrm{ml}$ of PBS. The cells were stimulated to differentiate towards chondrocytes as per the protocol (Miura 2002) for 30 minutes in $\alpha$-MEM medium with the supplement of 100 $\mathrm{ng} / \mathrm{ml}$ of human recombinant TGF- $\beta_{1}$ (R\&D Systems), $1 \%$ ITS (Insulin - Transferrin - Selenium, Gibco), $100 \mathrm{nM}$ of dexamethasone (DEXAMETAZON, Medochemie) and $50 \mathrm{mg} / \mathrm{ml}$ of ascorbate-2-phosphate solution (ASCORBÁT-2-FOSFÁT, Sigma). After induction, the cells were centrifuged $(700 \mathrm{~g}, 5 \mathrm{~min})$ and prepared to be transferred to a scaffold.

The scaffold was prepared at $4{ }^{\circ} \mathrm{C}$ by blending $20.75 \mu \mathrm{l}$ of sodium hyaluronate $(10 \mathrm{mg} / \mathrm{ml}, 1500 \mathrm{kDa}$ (SODIUM HYALURONAT, Contipro)) with $31.1 \mu 11 \mathrm{mg} / \mathrm{ml}$ of collagen type I solution (collagen type I was taken from calfskin kept in acid solvent) in 0.1-molar acetic acid (KYSELINA OCTOVÁ 99.8\%, Lach-ner, s.r.o.). The scaffold was neutralized in 1-molar kalium hydroxide (potash) (HYDROXID DRASELNÝ, Penta). Afterwards, a pipette was used to add $36 \mu \mathrm{l}$ of MSCs suspension $\left(2 \times 10^{6}\right.$ of cells each time). The medium containing $100 \mu \mathrm{g} / \mathrm{ml}$ of ascorbate-2-phosphate, $200 \mathrm{mM}$ of dexamethasone, 20\% FBS and ITS was supplemented with $0.12 \mathrm{ml}$ solution of human protein for Tissucol (TissucolRKit Baxter) in aprotinin (fibrinogen $70-110 \mathrm{mg} / \mathrm{ml}$, aprotinin 3000 $\mathrm{KIU} / \mathrm{ml})$ and $0.12 \mathrm{ml}$ of trombin solution $(4 \mathrm{IU} / \mathrm{ml})$ in $\mathrm{CaCl}_{2}(40 \mu \mathrm{mol} / \mathrm{ml}$, TissucolR Kit, Baxter). Gel was formed on a microtitration plate $(96 \mathrm{wells} / 300 \mathrm{ml} /$ well diameter $0.628 \mathrm{~cm})(\mathrm{TPT})$ at $37^{\circ} \mathrm{C}$. A mixture of scaffold and MSCs was kept in the incubator with humid atmosphere of $5 \% \mathrm{CO}_{2}$ at $37^{\circ} \mathrm{C}$ until the cells were implanted to an animal (after 1 - 6 hours).

Surgical procedures

Surgeries were performed under general anaesthesia. Before induction to anaesthesia enrofloxacin (BAYTRIL $2.5 \%$ inj. ad us. vet., Bayer) at the dose of $5 \mathrm{mg} / \mathrm{kg}$ was administered intravenously. Induction was achieved by intramuscular administration of midazolam $(1.00 \mathrm{mg} / \mathrm{kg}$ (DORMICUM inj., Roche)) + fentanyl (0.02 mg/kg (FENTANYL, Janssen) and medetomidine at the dose of $200 \mu \mathrm{g} / \mathrm{kg}$ (DOMITOR inj. a.u.v., Pfizer). Total inhalation anaesthesia was then maintained by a mixture of oxygen, nitrous oxide $(2: 3)$ and isoflurane, (FORANE, Abbott Laboratoires) using a non re-breathing system (Bain). The heart rate, respiratory rate, invasive blood pressure, endtidal partial pressure of carbon dioxide and saturation of haemoglobin by oxygen was monitored (DATEX Cardiocap II). As this combination of drugs causes a strong respiratory depression, all animals were connected to a controlled ventilation device.

Rabbits were placed in dorsal recumbence and the surgical site was routinely prepared for aseptic procedure on both knees. Lateral arthrotomy of the right stifle joint was performed by parapatellar incision. After visual localization of the growth plate, the battery-powered drill (Colibri system, SYNTHES, USA) was used to create a defect in the lateral part of the distal physis of the femur in order to cause damage exceeding $9 \%$ of the growth plate area (Gál et al. 2002; Janarv et al. 1998). Therefore, $3.5 \mathrm{~mm}$ drill bit (ACUFEX - MosaicPlasty Precision, Smith \& Nephew, USA) was used to bore a canal $12 \mathrm{~mm}$ in depth from the lateral surface of the lateral condyle dorsolaterally above the insertion of $\mathrm{m}$. extensor digitorum longus. The canal was drilled in a dorsomedial direction in order to cause damage to the lateral part of the distal femoral physis including adjacent parts of the epiphysis and metaphysis. Before implantation of the scaffold with autogenous MSCs, the canal was dilated using a $3.5 \mathrm{~mm}$ dilator (ACUFEX - MosaicPlasty Precision, Smith \& Nephew, USA). A mixture of the scaffold and MSCs was prepared in wells of a microtitration plate (TPT), from where the implant (in the form of a cylinder $3.5 \mathrm{~mm}$ thick and $10 \mathrm{~mm}$ long) was taken by the drill guide (ACUFEX - MosaicPlasty Precision, Smith \& Nephew, USA) (Plate X, Fig. 1) and carefully inserted using a delivery tamp (ACUFEX - MosaicPlasty Precision, Smith \& Nephew, USA) into the defect drilled in the lateral femoral condyle. In order to fix the transplant in its position, the canal was closed (on the lateral surface of the lateral condyle of the femur) with a cylinder made from beta-tricalcium phosphate (ChronOS, SYNTHES) $3.5 \mathrm{~mm}$ thick and $2 \mathrm{~mm}$ long, that was cut out from a preformed ChronOS block using $3.5 \mathrm{~mm}$ tubular chisel (ACUFEX - MosaicPlasty Precision, Smith \& Nephew, USA). The stifle joint was lavaged with Ringer Lactat solution (Ringer Lactat I.V.Inf., Braun Medical AG). The joint capsule was closed with an interrupted suture (polypropylene, Prolene 4/0, Ethicon). Subcutaneous layer was closed with a continuous suture using $2 / 0$ polyglactin 910 (Vicryl, Ethicon). The skin was closed with a simple interrupted suture using $2 / 0$ polyglactin 910 (Vicryl, Ethicon). Afterwards, a defect in the lateral part of the distal epiphyseal plate of the left 
femur was created similarly. However, the canal drilled in the condyle was not filled with an implant (i.e. the scaffold with autogenous MSCs), nor beta-tricalcium phosphate (ChronOS). This limb served as a control.

After the surgery, antagonization of all three anaesthetic components was performed using a combination of naloxon $(0.03 \mathrm{mg} / \mathrm{kg}$ (INTRENON inj., Léčiva a.s.)) + flumazenil (0.1 mg/kg (ANEXATE, Hoffmann-La Roche Ltd.)) + atipamezol (1.0 mg/kg (ANTISEDAN inj. ad us. vet., Pfizer Animal Health)) that was administered intramuscularly. Analgesia in post-operative period was achieved by application of carprofen (RIMADYL inj. ad us. vet., Pfizer Animal Health) at the dose of $2 \mathrm{mg} / \mathrm{kg} /$ day for three days after the surgery. Following recovery from surgery, the animals were allowed to walk freely and weight down as tolerated. During whole study period, the animals were fed, handled and housed according to the welfare principles (Sýkora et al. 1983). At the end of the experiment (4 months after the surgery), all animals were euthanized lege artis. First, they were put under general anaesthesia using intravenous thiopental at the dose of $20 \mathrm{mg} / \mathrm{kg}$. Then they were given intravenous T $61 \mathrm{inj}$. ad us. vet. (Hoechst Roussel Vet.) at the dose of $1 \mathrm{ml}$ pro toto.

Length and angular (valgus) deformity of the operated bone was measured from radiographs in craniocaudal (CC) projection. The quality of graft incorporation was evaluated histologically. The presence of transplanted cells in the physis was detected by immunofluorescence. All procedures were carried out with the consent of the Ethical Committee (No. 46613/2003-1020).

Bone length discrepancy and femoral valgus deformity measurements

Each rabbit was subjected to radiological examination on the day of transplantation and immediately after euthanasia. Bone length discrepancy and valgus deformity were measured from radiographs. Measurement of the length of the right femur (with the physeal defect and transplanted MSCs) and the left femur (with the physeal defect without transplanted MSCs) was done from radiographs of the femur in a craniocaudal (CC) projection. Actual length of the femur and the angle of the valgus deformity of the distal femur were measured (Plate X, Fig. 2). The measurements were performed separately by three independent observers. The measured values were averaged to calculate the arithmetic mean.

Histological findings

Healing of the defect was investigated histologically using haematoxylin and eosin staining. Following the excision of femurs of euthanized rabbits, femoral distal epiphyses were placed in $10 \%$ solution of formalin and stabilized. They were then decalcified and gradually dehydrated in solutions with increasing concentration of alcohol to enable embedding them in paraffin. Ultrathin paraffin sections of the distal femur $0.1 \mathrm{~mm}$ in thickness were stained with hematoxylin and eosin (HE) and subjected to microscopy. The site of the defect in growth plate of the femur was examined histologically.

On the basis of immunofluorescence detection of CM-DiI stain incorporated into the cell wall, these examinations should have proved, whether chondrocytes present in the defect originate from the implanted colony of autogenous MSCs or not.

Statistical evaluation

Means and standard deviations were calculated for the length and valgus deformity of the right femur (with the physeal defect and transplanted MSCs) and the left femur (with the physeal defect without transplanted MSCs) as well as for differences in length and angular deformities before MSCs transplantation and after euthanasia. The values were statistically analyzed using Wilcoxon matched-pairs test; STATISTICA (data analysis software system), version 7.1 (StatSoft, Inc. 2005).

\section{Results}

There were no complications during collection of bone marrow blood from iliac wings. In all ten rabbits, we successfully cultured MSCs autotransplant in the required quality, with an average count of cells $16 \times 10^{6}\left(16 \times 10^{6} \pm 14 \times 10^{6}\right)$. In all cases, the required count of MSCs in the implant was at least $2 \times 10^{6}$ cells. There were no anaesthesia and post-operative complications in any of the animals. The wounds were healed per primam intentionem.

Results of measurement of femur lengths (Table 1) show that the right femurs with damaged distal growth zone and transplanted MSCs grew more in length $(0.61 \pm 0.19 \mathrm{~cm})$ as compared with the left femurs with physeal defect without transplanted MSCs $(0.11 \pm 0.07 \mathrm{~cm})$. Angular (valgus) deformity of right femurs with physeal defect and transplanted MSCs was mild $\left(1.2^{\circ} \pm 0.72^{\circ}\right)$. On the contrary, left femurs with the physeal defect without transplanted MSCs showed significant valgus deformity $\left(5.4^{\circ} \pm 2.5^{\circ}\right)$ (Plate XI, Fig. 3). Differences in lengths and valgus deformity (Fig. 5) were statistically significant $(5 \%$ level of significance, $p=0.018)$.

Table 2 demonstrates histological and immunofluorescence findings of preparations of the distal femoral physis. Histological examination of sections of the distal part of the femur 
Table 1. Length and valgus deformity of femurs measured from radiographs in CC projection in rabbits. Right femurs (R) with autogenous MSCs transplanted into physeal defects; left femurs (L) with physeal defects but without transplanted MSCs.

\begin{tabular}{|c|c|c|c|c|c|c|c|c|c|c|c|c|}
\hline \multirow[b]{2}{*}{ Animal } & \multicolumn{2}{|c|}{$\begin{array}{l}\text { Length of right } \\
\text { femur }(\mathrm{cm})\end{array}$} & \multicolumn{2}{|c|}{$\begin{array}{l}\text { Length of left } \\
\text { femur }(\mathrm{cm})\end{array}$} & \multicolumn{2}{|c|}{$\begin{array}{l}\text { Length } \\
\text { of femur } \\
(\mathrm{cm})\end{array}$} & \multicolumn{2}{|c|}{$\begin{array}{l}\text { Valgus deformity } \\
\text { of right femur }\left(^{\circ}\right)\end{array}$} & \multicolumn{2}{|c|}{$\begin{array}{c}\text { Valgus } \\
\text { deformity of } \\
\text { left femur }\left({ }^{\circ}\right)\end{array}$} & \multicolumn{2}{|c|}{$\begin{array}{c}\text { Difference } \\
\text { in femoral } \\
\text { deformities }\left({ }^{\circ}\right)\end{array}$} \\
\hline & Preop & $\begin{array}{c}\text { After } \\
\text { euthanasia }\end{array}$ & Preop & $\begin{array}{c}\text { After } \\
\text { euthanasia }\end{array}$ & $\mathrm{R}$ & $\mathrm{L}$ & Preop & $\begin{array}{c}\text { After } \\
\text { euthanasia }\end{array}$ & Preop & $\begin{array}{c}\text { After } \\
\text { euthana- } \\
\text { sia }\end{array}$ & $\mathrm{R}$ & $\mathrm{L}$ \\
\hline Aut1 & 9.1 & 9.5 & 9.5 & 9.5 & 0.4 & 0.0 & 0 & 1 & 2 & 6 & 1 & 4 \\
\hline Aut2 & 9.2 & 10.0 & 9.4 & 9.6 & 0.8 & 0.2 & 2 & 3 & 1 & 6 & 1 & 5 \\
\hline Aut3 & 9.2 & 9.6 & 9.3 & 9.4 & 0.4 & 0.1 & 1 & 1 & -1 & -1 & 0 & 0 \\
\hline Aut4 & 9.0 & 9.5 & 9.2 & 9.3 & 0.5 & 0.1 & 3 & 4 & 3 & 8 & 1 & 5 \\
\hline Aut5 & 9.1 & 9.5 & 9.1 & 9.1 & 0.4 & 0.0 & 0 & 2 & 2 & 4 & 0 & 2 \\
\hline Aut6 & 9.5 & 9.9 & 9.6 & 9.7 & 0.4 & 0.1 & 1 & 2 & 8 & 14 & 1 & 6 \\
\hline Aut7 & 8.8 & 9.6 & 9.5 & 9.5 & 0.8 & 0.0 & 2 & 3 & 9 & 13 & 1 & 4 \\
\hline Aut8 & 8.9 & 9.9 & 9.1 & 9.3 & 1.0 & 0.2 & 1 & 5 & 2 & 12 & 4 & 11 \\
\hline Aut9 & 8.8 & 9.6 & 8.8 & 9.0 & 0.8 & 0.2 & 3 & 4 & 6 & 17 & 1 & 11 \\
\hline Aut10 & 8.8 & 9.4 & 8.8 & 9.0 & 0.6 & 0.2 & 5 & 7 & 6 & 12 & 2 & 6 \\
\hline
\end{tabular}

Table 2. Results of histological evaluation of distal femoral physeal preparations and immunofluorescence detection of CM-DiI stained autogenous MSCs transplanted into the physeal defect.

\begin{tabular}{|c|c|c|}
\hline Animal & Result of histological examination (HE) & MSCs detected by imunofluorescence \\
\hline Aut1 & ++ & + \\
\hline Aut2 & +++ & + \\
\hline Aut3 & ++ & + \\
\hline Aut4 & ++ & + \\
\hline Aut5 & + & + \\
\hline Aut6 & +++ & + \\
\hline Aut7 & + & + \\
\hline Aut8 & ++ & - \\
\hline Aut9 & - & + \\
\hline Aut10 & ++ & + \\
\hline
\end{tabular}

+ ) positive finding - Histology - finding of chondrocytes islets in physeal defects

- Imunofluorescence - finding of IFS stain on membranes of chondrocytes

++ ) histological finding (HE) - defect is filled with hyaline cartilage without columnar cell formation

+++ ) histological finding (HE) - defect is filled with hyaline cartilage with columnar cell formation

-) negative finding

stained with hematoxylin and eosin proved the presence of chondrocytes in the distal growth plate of the right femur after the transplantation of autogenous MSCs to this part of the physis. Histology also detected three forms of newly created cartilaginous tissue at the site of MSCs transplantation. They were chondrocyte islets (Plate XI, Fig. 4a), hyaline cartilage (without columnar formation of chondrocytes) in the physeal defect (Plate XI, Fig. 4b) and hyaline cartilage (with columnar-like arrangement of cells in the defected part of the growth plate (Plate XI, Fig. 4c). In one case, no chondrocytes were found in the physeal defect treated by transplantation of MSCs.

Immunofluorescence examination proved in nine cases that parts of membranes of newly formed chondrocytes located at the site of the physeal defect treated by MSCs transplantation (right femur) were stained with lipophilic fluorescence stain (CM-DiI) . 
B.

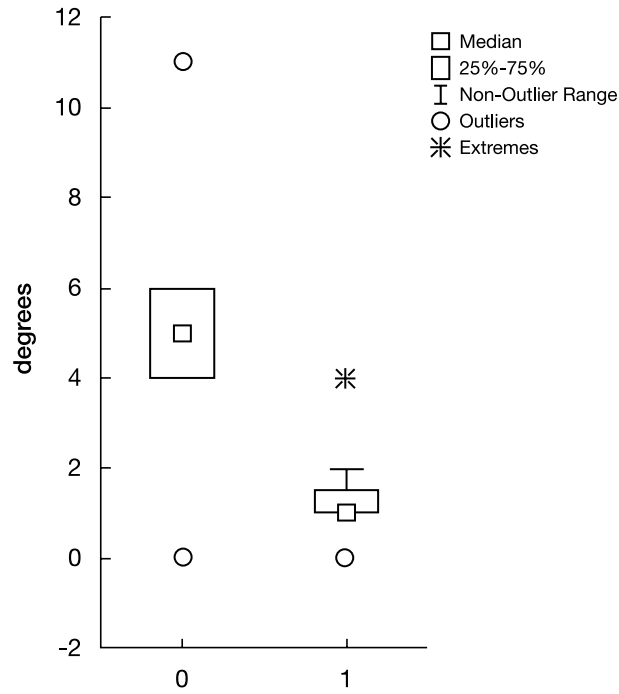

Graph 1. Comparison of growth (A) and valgus deformity (B) in left femur without transplanted MSCs (0) and growth cartilage (1). in right femur with transplanted MSCs to the defect of

\section{Discussion}

In our previous study, we reported on successful prevention of the bone bridge formation and growth arrest using autogenous chondrocyte graft transplantation into iatrogenically damaged physis in pigs (Gál et al. 2002). The main goal of the present study was to find out whether it is possible to use MSCs to prevent bone bridge formation and the development of growth defects with valgus deformity of the femur. As an experimental model we used the New Zealand white rabbit which is successfully and commonly used in studies of this kind (Chen et al. 2003; Cohen et al. 2003; Lee et al. 2004). Existing studies on MSCs transplantation searched only for methods of bone bridge treatment through inducing and investigating the defect in the proximal growth plate of rabbit tibia (Chen et al. 2003; Ahn et al. 2004; Hui et al. 2005). Instead, we chose the distal femoral physis as a model site of iatrogenic damage of the growth plate for the following two reasons: First, injury of this physis is seen very often both in human and veterinary clinical practice (unlike injury of the proximal tibial physis) (Ashcraft 2005; Maretta and Schrader 1983); and second, the distal femoral physis is critical for the longitudinal growth of the femur (Olson et al. 1975; Maretta and Schrader 1983). Moreover, we employed our own MSCs transplantation technique using a newly modified gel scaffold which should have proved suitable for the growth and survival of mesenchymal stem cells and, at the same time, enable transplantation of cells to the damaged physis with the help of arthroscopy.

In order to obtain valid results, we chose, tried and tested the methodology of collecting, culturing and differentiation of autogenous mesenchymal stem cells. The MSCs were separated from bone marrow blood taken from the ilium which is suitable and the most common site of MSCs collection (Quintavalla et al. 2002; Wang et al. 2006; JuncovaMelvin et al. 2006). Other published methods of MSCs collection include isolation of cells from periosteal blocks (Chen et al. 2003; Caplan 2005) or from the abdominal wall subcutaneous fat (Hui et al. 2005). In our study, collection of bone marrow from the iliac wing was selected also with respect to the fact that this method is established and commonly used at the Institute of Animal Physiology and Genetics in Liběchov. Cultured MSCs were stimulated to differentiate towards chondrocytes as per protocol (Miura 2002) in $\alpha$-MEM medium with the supplement of human recombinant TGF- $\beta 1$. The culture medium was supplemented also with $1 \%$ ITS, dexamethasone and ascorbate-2-phosphate which are commonly used ingredients of culture and differentiation medium ( $\mathrm{Li}$ et al. 2005; Lisignoli et al. 2005; Indrawattana et al. 2004; Quintavalla et al. 2002). In some studies, MSCs were successfully differentiated using TGF- $\beta 3$ (Lee et al. 2004; Chen et al. 2004), in some cases combined with BMP-6 or IGF-1 (Indraw at tana et al. 2004). As the role of these factors and accurate timing of their application is not completely clear, we differentiated the MSCs using the TGF- $\beta 1$ alone, whose application is a commonly 
recognized method of influencing differentiation of mesenchymal stem cells toward chondrocytes (Lisignoli et al. 2005; Li et al. 2005; Hui et al. 2005). In our study, we used TGF- $\beta 1$ (at the concentration of $100 \mathrm{ng} / \mathrm{ml}$ ) to affect MSCs in medium for 30 minutes (Miura 2002). Today, higher concentrations of TGF- $\beta 1$ are recommended (Lisignoli et al. 2005); Hui et al. (2005) used TGF- $\beta 1$ even at the concentration of $1000 \mathrm{ng} / \mathrm{ml}$.

In this experiment, the marking of cells should have detected whether a newly formed tissue was the product of implanted autogenous MSCs or the defect was filled with other type of cells (local reaction of connective tissue). Although other methods of cell marking such as marking with CMTMR (Quintavalla et al.2002) have been described, we decided to use in vitro detection of implanted cells in the physeal defect by immunofluorescence examination of MSCs marked with CM-DiI (Ahn et al. 2004). We believe that this technique, in combination with histological assessment of tissue samples marked with haematoxylin-eosin, is simple, reliable, and affordable.

In accordance with the established goals, we tried to find a gel scaffold working as an effective nutrient medium that could fill the growth plate defect evenly. Also, we wanted the scaffold to be easily inserted in the damaged physis using an appropriate arthroscopic tool which makes it possible to safely lavage the operation site during arthroscopy, without destructing the scaffold structure. In our view, these requirements were met by a new threecomponent scaffold (New Composite Hyaluronate/Collagen Type I/Fibrin Scaffold), whose characteristics are similar to the natural environment of cartilaginous extracellular matrix. ACUFEX (MosaicPlasty Precision) instruments, particularly a drill guide $(3.5 \mathrm{~mm})$ and delivery tamp, proved to be the most suitable tools for withdrawing the scaffold with MSCs from the microtitration plate (Fig. 1) and implanting it to the site of the damaged distal physis of the femur. Also, we used a tubular chisel to cut out a cylinder ( $3.5 \mathrm{~mm}$ in diameter) of preformed ChronOS block. This cylinder was then used to close the canal in the lateral surface of the lateral femoral condyle in order to prevent shifting of the implant to the joint space of the knee.

When selecting the method to create the bone bridge iatrogenically, we built on the results of our previous study (Gál et al. 2002) and the experimental study of Jan arv et al. (1998). We believed that this tried and tested method, causing damage to more than $9 \%$ of the growth plate area, was highly dependable.

The proper clinical verification of the impact of preventive MSCs transplantation into the defect in the femoral distal physis on longitudinal bone growth and on the degree of incurred valgus deformity was based on the measuring of these quantities from X-ray photographs of the femur in a craniocaudal projection. The femoral length was measured as the distance between the femur head tip and the tangent of the most distant point of the femoral condyle (Janarv et al. 1998); the degree of valgus deformity of the distal femur was measured as the angle between the long axis of the bone and the vertical to the tangent connecting the femoral condyles (Fig. 2). We expected that the right femur with a defect in the lateral section of the growth plate would be, due to preventive transplantation of MSCs, longer and less valgus deformed (or entirely without valgus deformity) than the left femur with the same physis defect, but without MSCs transplantation (i.e. a bone bridge bridging the physis). This hypothesis was confirmed by measurements made by three independent observers. The average difference in the femoral length between operation and euthanasia (i.e. the scope of bone growth) was, in case of the right femur after preventive transplantation MSCs $0.61 \pm 0.19 \mathrm{~cm}$, whereas in case of the left femur it was only $0.11 \pm 0.07 \mathrm{~cm}$ (Fig. 5). The average angular (valgus) deformity of the right femur with preventively transplanted MSCs into iatrogenically created defect in the femoral distal physis was $1.2^{\circ} \pm 0.72^{\circ}$, while in case of the left femur; its valgus deformity was $5.4^{\circ} \pm 2.5^{\circ}$ (Fig. 5). The difference in the measured values of both indicators was 
statistically significant at $5 \%$ significance level $(p=0.018)$. The right femur, in contrast to the left femur, grew more in length. Its valgus deformity, compared to the left femur, was minimal and clinically non-significant (Table 1).

The character of the new cartilaginous tissue and verification whether this is a hyaline cartilage structurally similar to the cartilage of the growth plate was based on histological examination after the experimental animals were euthanized and bone blocks with the femoral distal physis were processed for this histological examination. In the area of the distal growth plate of the left femur, where MSCs were not transplanted preventively, we expected the histological examination to find newly created bone beams, as an expression of the bone bridge that replaced the original tissue of growth cartilage. To the contrary, in the distal growth plate of the right femur (after preventive MSCs transplantation) we expected filling of the defect with hyaline cartilaginous tissues whose structure would resemble physeal growth zone of the bone. In nine out of ten cases (Table 2) we demonstrably found in histological sections of the distal physis of the right femur (HE colouring) newly created hyaline cartilage in various developmental stages in relation to cell organization (Fig. 4). In two cases these were only zones of created hyaline cartilage in the physeal defect otherwise filled with fibrous cartilage, in five cases the physeal defect filled with hyaline cartilage without further cell organization, and in two cases, chondrocytes were formed in columns in individual layers of physiologically organized growth plate (Fig. 4; Table 2).

Apart from histological examination of dissections of the femoral distal growth plate we used immunofluorescence to assess the quality and origin of newly created cartilaginous tissue in iatrogenically created physeal defect (Vimentin, CM-DiI coloring). Immunofluorescence proved the presence of CM-DiI hue in the growth zone in all nine cases, when the presence of newly created hyaline cartilaginous tissue was confirmed already in histological sections stained with HE (Table 2). The importance of immunofluorescence examination findings lies in the fact that we have proved that the new growth zone chondrocytes really originated from by us implanted and in vitro MSCs stained before transplantation. In one case, when cartilaginous tissue was proven neither in the growth zone nor in the histological section, CM-DiI hue was not proven by immunofluorescence with stained HE either.

As opposed to the previously used cultivated autologous chondrocytes (Gál et al. 2002), during preventive transplantation of MSCs to the physis, it is not necessary to sample a cartilage graft from the unloaded joint surface of the femur, which spares one intervention (be it arthroscopic or arthrotomic) into the joint. This limits the chances of development of osteoarthritis due to creation of cartilage defect, which prevents possible complications related to chirurgical intervention into the joint (septic arthritis, etc.). During transplantation of autogenous MSCs, this intraarticular intervention is replaced by bone marrow blood sampling from a place outside the joint, in our case from the wing of the hip bone.

The results of this experimental study in rabbits confirmed our hypothesis that transplantation of autogenous mesenchymal stem cells into an experimental physeal defect can prevent bone bridge formation and thereby bone shortening and angular (valgus) deformity. The procedure can promote healing of the damaged growth plate by differentiation of transplanted MSCs into chondrocytes. The physeal defects can heal by hyaline cartilage.

Clinical importance of these findings might be in prevention of serious consequences of the closure of the long bone growth plates. To prevent the origination of a bone bridge by preventive transplantation of autogenous MSCs into an injured physis could lead, after verification in clinical practice, to a new approach to physis trauma treatment. As the purpose of preventive transplantation of autogenous MSCs is to preserve bone growth from 
traumatized physis, this approach could prevent any bone deformities. If we diagnose the development of a bone bridge in time, e.g. by using MRI (Cheon et al. 2005), it would not be necessary to use frequently complicated surgical interventions treating the shortening of the angular bone deformities (due to a physis closure) after they originate.

In spite of these positive results with experimental use of autogenous MSCs in a damaged physis in rabbits, numerous questions related to in vivo transplantations of mesenchymal stem cells remain to be answered. It appears to be suitable to examine these experiences in other (larger) animal models, and then perhaps in clinical patients. Within the frame of our study, it will be necessary to test other carriers of stem cells, growth factors, and surgical techniques as well, to achieve the best possible integration of transplanted MSCs into the target tissue. In view of possible efforts to use MSCs directly to heal joint - epiphyseal complex cartilage defects resulting from acute trauma, it will be necessary to examine the possibilities of using allogenic mesenchymal stem cells. In this regard, numerous problems arise in relation to preservation, but also questions in relation to immunosuppression. And last, but not least, regarding MSCs transplantations into the musculoskeletal system, it will be necessary to carry out long-term monitoring of animals for possible side effects associated with the use of stem cells.

In conclusion, preventive transplantation of autogenous mesenchymal stem cells into a iatrogenically created defect in the femoral distal growth plate in the rabbit prevented origination of a bone bridge and healed the physeal defect by hyaline cartilage. Immunofluorescence examination proved that the newly created chondrocytes originated in the growth zone as a result of differentiation of implanted MSCs. Growth of the right femur in the traumatized physis was preserved after transplantation of autogenous MSCs and, compared to the left femur (with a physeal defect but without transplanted MSCs), substantial shortening and valgus deformity of the bone did not occur $(p=0.018)$.

The results of this study indicate the possibility of a preventive use of autogenous MSCs by implantation into the defect of damaged growth cartilage in the rabbit, before creation of a bone bridge without shortening and development of angular (valgus) bone deformity.

\section{Prevence vzniku kostního můstku transplantací autogennních mezenchymových kmenových buněk do fyzárních defektů: experimentální studie u králíků}

Regenerační kapacita fyzárních růstových plotének je po jejich traumatizaci nízká. Hodnocení schopnosti mezenchymových kmenových buněk hojit defekty v poraněné fýze patří mezi aktuální otázky současného výzkumu. V této studii byly u 10 novozélandských bílých králíků transplantovány autogenní mezenchymové kmenové buňky do iatrogenního defektu v laterálním úseku distální fýzy femuru. Stejný defekt bez transplantace kmenových buněk v distální fýze levého femuru sloužil jako kontrola. Použili jsme vlastní techniku implantace MSCs s nově modifikovaným gelovým skafoldem (nový kompozit hyaluronátu/kolagenu typu I/fibrinu). Králíci byli utraceni 4 měsíce po transplantaci. Rozdíly $\mathrm{v}$ délce a valgózní deformitě kosti byly měřeny $\mathrm{z}$ rentgenogramů femurů. Hojení defektů bylo hodnoceno histologicky. Schopnost mezenchymových kmenových buněk přežít v poškozené fýze a podporovat hojení její chrupavky byla stanovena na základě imunofluorescence.

Průměrný rozdíl v délce femuru od operace do utracení (4 měsíce), byl v případě pravého femuru po preventivní transplantaci MSCs $0,61 \pm 0,19 \mathrm{~cm}$, zatímco u femuru levého pouze $0,11 \pm 0,07 \mathrm{~cm}$. Průměrná angulární (valgózní) deformita pravé stehenní kosti s preventivně transplantovanými MSCs do iatrogenně vytvořeného defektu v distální fýze femuru byla $1,2 \pm 0,72^{\circ}$, zatímco v případě levého femuru byla jeho valgózní deformita $5,4 \pm 2,5^{\circ}$.

Preventivní transplantace autogenních mesenchymových kmenových buněk do iatro- 
genně vytvořeného defektu v distální růstové ploténce femuru u králíka vedla k zábraně vzniku kostního můstku a zhojení defektu ve fýze hyalinní chrupavkou. Imunofluorescenčním vyšetřením bylo prokázáno, že v růstové zóně nově vytvořené chondrocyty vznikly diferenciací implantovaných MSCs. Růst femuru v traumatizované fýze byl po transplantaci autogenních MSCs zachován, a v porovnání s protilehlým femurem (s defektem ve fýze a bez transplantace MSCs) nedošlo k výraznému zkrácení a valgózní deformitě kosti $(p=0,018)$.

\section{Acknowledgement}

This work was supported by the Ministry of Health of the Czech Republic (Research Projects of IGA MZ CR NR8483-2/2005), Ministry of Education, Youth and Sport of the Czech Republic (NPV II 2B06130) and by Grant Agency AGEL-MH. We are grateful to MVDr. Dušan Usvald and MVDr. Jana Hlučilová from the UZFG AV CR Liběchov for preparation of the stem cells. We also thank to Doc. RNDr. Evžen Amler for providing scaffolds used in the study.

\section{References}

AHN JI, CANALE TS, BUTLER SD, HASTY KA 2004: Stem cell repair of physeal cartilage. J Orthop Res 22: 1215-1221

ASHCRAFT KW 2005: Pediatric Surgery. $4^{\text {th }}$ ed. Elsevier Saunders, Philadelphia, pp. 229-231

BRIGHT RW 1974: Operative correction of partial epiphyseal plate closure by osseous-bridge resection and silicon-rubber implant. J Bone Joint Surg Am 56: 655-664

BROUGHTON NS, DICKENS DRV, COLE WG, MENELAUS MB 1989: Epiphysiolysis for partial growth plate arrest. J Bone Join Surg Br 71: 13-16

CAMPBELL CJ, GRISOLIA A, ZANCONATO G 1959: The effects produced in the cartilaginous epiphyseal plate of immature dogs by experimental surgical traumata. J Bone Joint Surg Am 41: 1221- 1242

CAPLAN AI 2005: Review: Mesenchymal Stem Cells: Cell-Based Reconstructive Therapy in Orthopedics. Tissue Eng 11: 1198

CHEN F, HUI JHP, CHAN WK, LEE EH 2003: Cultured mesenchymal stem cell transfers in the treatment of partial growth arrest. J Pediatr Orthop 23: 425-429

CHEN G, LIU D, TADOKORO M, HIROCHIKA R, OHGUSHI H, TATEISHI T, TANAKA J 2004: Chondrogenic diferentiation of human mesenchymal stem cells cultured in cobweb-like biodegradable scaffold. Biochem Biophys Res Commun 322: 50-55

CHEON JE, KIM IO, CHOI IH, KIM CJ, CHO TJ, KIM WS, YOO WJ, YEON KM 2005: Magnetic resonance imaging of remaining physis in partial physeal resection with graft interposition in a rabbit model: a comparison with physeal resection alone. Invest Radiol 40: 235-242

COHEN SB, MEIRISCH CM, WILSON HA, DIDUCH DR 2003: The use of absorbable co-polymer pads with alginate and cells for articular cartilage repair in rabbits. Biomaterials 24: 2653- 2660

DVOŘ́K M, NEČAS A, ZATLOUKAL J 2000: Complications of long bone fracture healing in dogs: functional and radiological criteria for their assessment. Acta Vet Brno 69: 107-114

FORD LT, KEY JA 1956: A study of experimental trauma to the distal femoral epiphysis in rabbits. J Bone Joint Surg Am 38: 84-92

FOSTER BK, HANSEN AL, GIBSON GJ, HOPWOOD JJ, BINNS GF, WIEBKIN OW 1990: Reimplantation of growth plate chondrocytes into growth plate defects in sheep. J Orthop Res 8: 555-564

FOX SM 1984: Premature closure of distal radial and ulnar physes in the dog. Part I. Pathogenesis and diagnosis. Compend Cont Educ Pract Vet 6: 128

GÁL P, NEČAS A, ADLER J, TEYSCHL O, FABIÁN P, BIBROVÁ Š 2002: Transplantation of the autogenous chondrocyte graft to physeal defects: an experimental study in pigs. Acta Vet Brno 71: $327-332$

GÁL P, TEYSCHL O, KECOVÁ H, FABIÁN P, BIBROVÁ Ś 2002: The influence of transphyseal pin placement on bone growth: an experimental study in pigs. Acta Vet Brno 71: 319-325

HENNEY LH, GAMBARDELLA PC 1989: Premature closure of the ulnar physis in the dog: A retrospective clinical study. J Am Anim Hosp Assoc 25: 573-581

HUI JHP, LI L, TEO YH, OUYANG HW, LEE EH 2005: Comparative study of the ability of mesenchymal stem cells derived from bone marrow, periosteum, and adipose tissue in treatment of partial growth arrest in rabbit. Tissue Eng 11: 904-912

INDRAWATTANA N, CHEN G, TADOKORO M, SHANN LH, OHGUSHI H, TATEISHI T, TANAKA J, BUNYARATVEJ A 2004: Growth factor combination for chondrogenic induction from human mesenchymal stem cell. Biochem Biophys Res Commun 320: 914-919

JANARV PM, WIKSTROM B, HIRSCH G 1998: The influence of transphyseal drilling and tendon grafting on bone growth: an experimental study in the rabbit. J Pediatr Orthop 18: 149-154

JUNCOSA-MELVIN N, BOIVIN GP, GALLOWAY MT, GOOCH C, WEST JR, BUTLER DL 2006: Effects of Cell-to-Collagen Ratio in Stem Cell-Seeded Constructs for Achilles Tendon Repair. Tissue Eng 12: 681-689 
KEY JA, FORD LT 1958: A study of experimental trauma to the distal femoral epiphysis in rabbits - II. J Bone Joint Surg Am 40: 887-896

KLASSEN RA, PETERSON MA 1982: Excision of physeal bars: the Mayo Clinic experience 1968 - 1978. Orthop Trans 2: 65

LANGENSKIOLD A 1981: Surgical treatment of partial closure of the growth plate. J Pediatr Orthop 1: 3-11

LEE EH, CHEN F, CHAN J, BOSE K 1998: Treatment of growth arrest by transfer of cultured chondrocytes into physeal defects. J Pediatr Orthop 18: $155-160$

LEE JW, KIM YH, KIM SH, HAN SH, HAHN SB, YONSEI 2004: Chondrogenic Differentiation of Mesenchymal Stem cells and its clinical applications, Med J 45: 41-47

LEE KM, LOK AS CHENG, CHEUNG WH, LUI PPY, OOI V, FUNG KP, LEUNG PC, LEUNG KS 2003: Bioengineering and Characterization of Physeal Transplant with Physeal Reconstruction Potential. Tissue Eng 9: 703-711

LENNOX DW, GOLDNER RD, SUSSMAN MD 1983: Cartilage as an interposition material to prevent transphyseal bone bridge formation: an experimental model. J Pediatr Orthop 3: 207-210

LI WJ, TULI R, OKAFOR C, DERFOUL A, DANIELSON KG, HALL DJ, TUAN RS 2005: A three-dimensional nanofibrous scaffold for cartilage tissue engineering using human mesenchymal stem cells. Biomaterials 26: 599-609

LISIGNOLI G, CRISTINO S, PIACENTINI A, TONEGUZZI S, GROSSI F, CAVALLO C, ZINI N, SOLIMANDO L, NARALDI NM, FICCHINI A 2005: Cellular et molecular events dutiny chondrogenesis of human mesenchymalstromal cells grown in three-dimensional hyaluronan based scaffold. Biomaterials 26: 5677-5686

MACKSOUD WS, BRIGHT R. Bar resection and silastic interposition in distal radial physeal arrest. Orthop Trans 13: $1-2$

MANN DC, RAJMAIRA S 1990: Distribution of physeal and nonphyseal fractures in 2650 long-bone fractures in children aged 0-16 years. J Pediatr Orthop 10: 713

MARETTA SM, SCHRADER SC 1983: Physeal injuries in the dog: A review of 135 cases. J Am Vet Med Assoc 182: 708-710

MIURA Z, PARVIZI J, FITZSIMMONS JS, 2002: Brief exposure to high-dose transforming growth factor-beta1 enhances periosteal chondrogenesis in vitro: a preliminary report. J Bone Joint Surg Am 84-A: 793-799

MIZUTA T, BENSON WM, FOSTER BK 1987: Statistical analysis of the incidence of physeai injuries. J Pediatr Orthop 7: 518-523

NEČAS A, GÁL P, ADLER J, KECOVÁ H, FABIÁN P, BIBROVÁ Š 2006: Transplantation of the Autogenous Chondrocyte Graft to Physeal Defects: An Experimental Study. Proceedings of the 2nd Annual World Orthopedic Congress, 25.2. - 4.3.2006, Keystone, Colorado, USA, p. 236

OLSON NC, CARRIG CB, BRINKER WO 1975: Effects of asynchronous growth of the radius and ulna on the canine elbow joint following experimental retardation of longitudinal growth of the ulna. J Am Anim Hosp Assoc 77: 560

PIERMATTEI DL, FLO GL 1990: Brinker, Piermattei, and Flo's Handbook of Small Animal Orthopaedics and Fracture Treatment. 3rd ed., Philadelphia, W. B. Saunders, pp. 681-682

QUINTAVALLA J, UZIEL-FUSI S, YIN J, BOEHNLEIN E, PASTOR G, BLANCUZZI SINGH HN, KRAUS KH, O'BYRNE E, PELLAS TC 2002: Fluorescently labeled mesenchymal stem cells (MSCs) maintain multilineage potential and can be detected following implantation into articular cartilage defects. Biomaterials 23: 109-119

ROGERS LF 1970: The radiology of epiphyseat injuries. Radiology 96: 289-299

SALTER RB, HARRIS WR 2001: Injuries involving the epiphyseal plate. J Bone Joint Surg Am 83: 1753

StatSoft, Inc. (2005). STATISTICA (data analysis software system), version 7.1. www.statsoft.com.

SÝKORA I, DYNTEROVÁ A, HOLDA J, MARHAN O 1983: Chov laboratorních zvířat. Institut výchovy a vzdělávání MZVž Praha.

WANG Z, GOH J, DAS DE S, GE Z ET AL 2006: Efficacy of bone marrow-derived stem cells in strengthening osteoporotic bone in a rabbit model. Tissue Eng 12: 1753

WILLIAMSON RV, STAHELI LT 1990: Partial physeal growth arrest: treatment by bridge resection and fat interposition. J Pediatr Orthop 10: 769-776 
Plate X

Plánka L. et al.: Prevention of Bone ... pp. 253-263

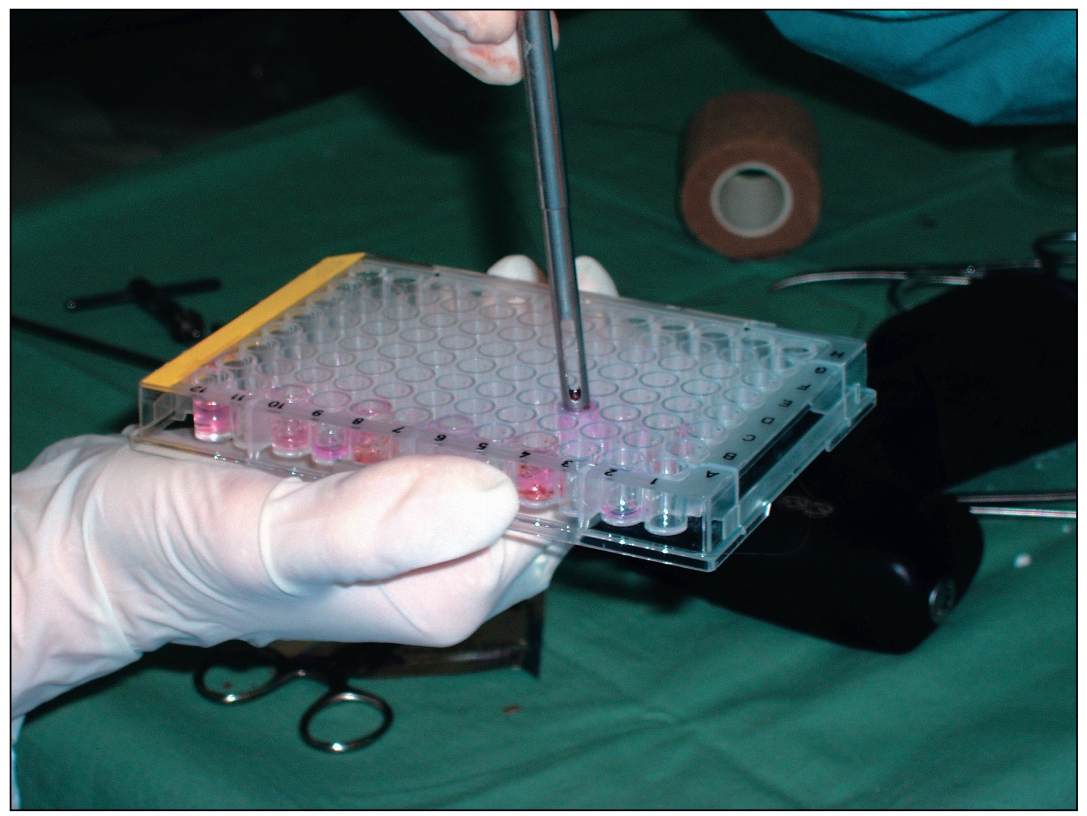

Fig, 1, Transition of scaffold with MSCs in the form of cylinder with $3.5 \mathrm{~mm}$ diameter and 10 $\mathrm{mm}$ height from a recession of a micro titration plate (TPT) using a drill guide) (ACUFEX MosaicPlasty Precision, Smith \& Nephew, USA)

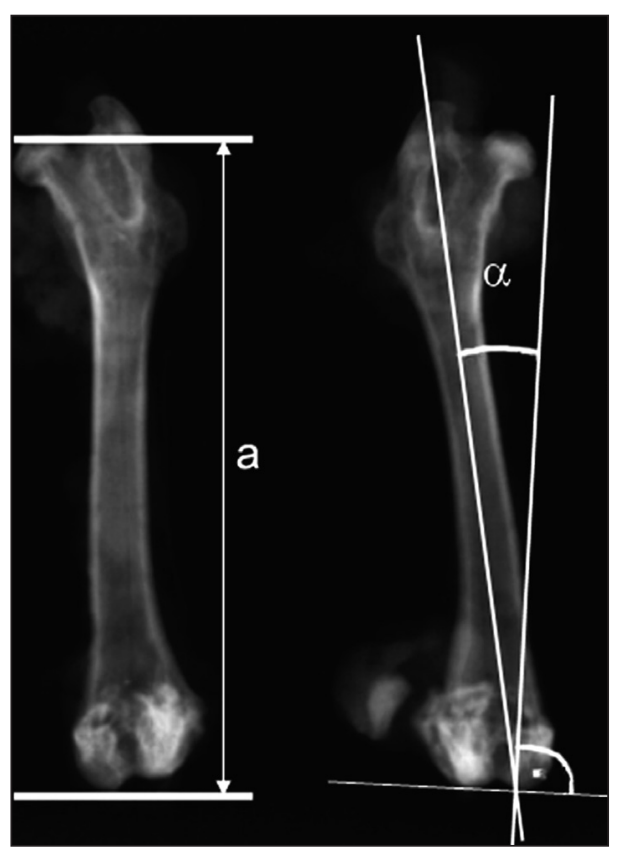

Fig. 2. Schematic drawing of measurement of the femoral lenght (a) and valgus deformity (a) from femoral radiographs. 


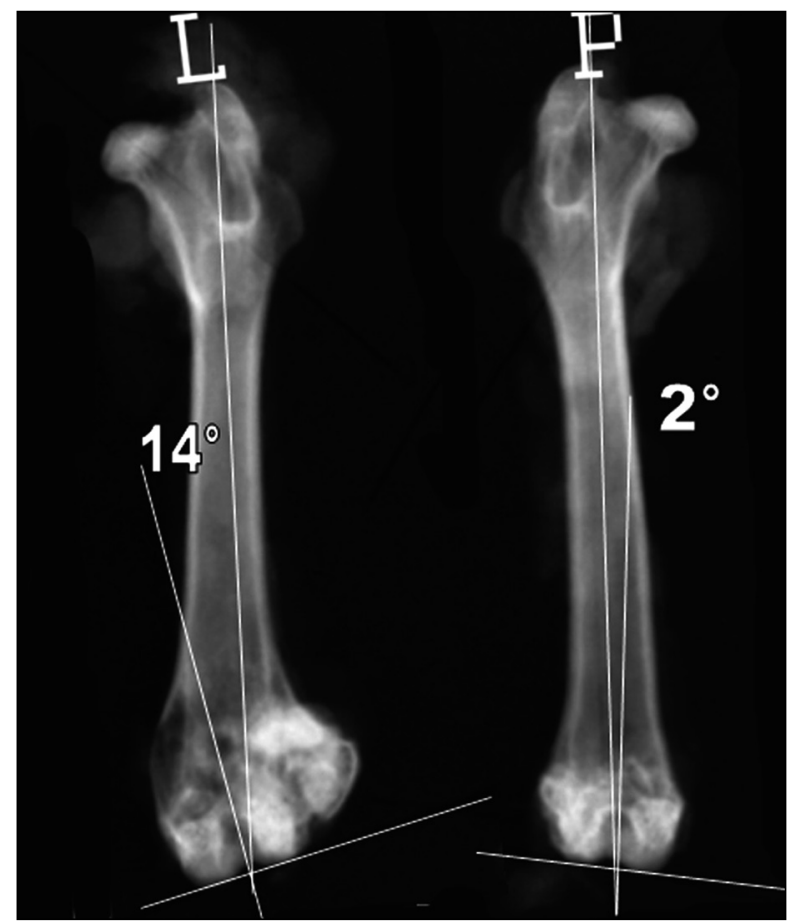

Fig. 3. Valgus deformity of the distal section of the left (L) femur (without transplantation of MSCs into the growth zone defect) and the right (P) femur in rabbit (Aut 6). Measured from X-ray photographs of femurs in CC projection after euthanasia (4 months after transplantation of MSCs).

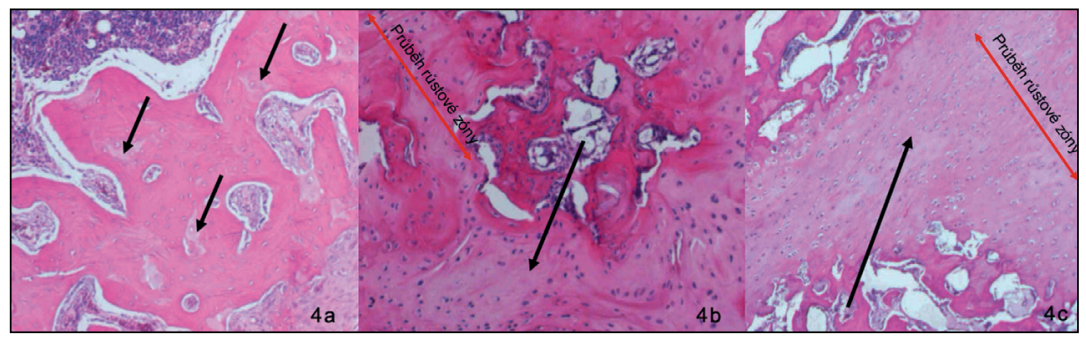

Fig. 4: Histological examina-tion of the distal femoral physis in rabbits after auto-genous MSCs transplan-tation (HE stain, $\times 40$ )

$4 \mathrm{a}$ - arrows points to isolated cartilages islets in the defect of growth cartilage (rabbit AUT 5) $4 \mathrm{~b}$ - red arrow indicates the shape of growth zone; black arrow points to newly formed hyaline cartilage present in the defect (rabbit AUT 8)

$4 \mathrm{c}$ - red arrow points to the shape of growth zone; black arrow indicates the site of the original defect filled with newly formed cartilage and outlined by a columnar formation (rabbit AUT 6) 